\title{
Changes in motivation as expertise develops: Relationships with musical aspirations
}

\author{
Susan Hallam, Andrea Creech, Ioulia Papageorgi, Teresa Gomes, Tiija Rinta, \\ Maria Varvarigou and Jennifer Lanipekun
}

Contact: Susan Hallam, University College London, Institute of Education, 20 Bedford Way, London, WC1H OAL

s.hallam@ioe.ac.uk

\begin{abstract}
Recent models of musical motivation have recognised the complex interactions which occur between environmental (cultural, institutional, familial, educational) and internal factors (cognition and affect) in enhancing or reducing motivation. Much previous research has been small scale and not taken account of long term musical aspirations. This paper aims to address these issues exploring changes in motivation as expertise develops with a large sample of learners. 3325 young musicians, aged 6-19 playing a wide range of instruments participated, They represented nine levels of expertise ranging from beginner to higher education conservatoire entry level. Level of expertise was established in terms of the most recent graded independent instrumental examination taken. They were asked to respond to a series of statements on a 7 point Likert scale. The statements focused on well-established elements of motivation including: self-beliefs; enjoyment of musical activities; enjoyment of performance; level of support received from parents, friends and teachers; attitudes towards playing an instrument and perceptions of its value; and beliefs about the importance of musical ability. Participants were also asked to respond to statements about their long term musical aspirations. An exploratory factor analysis provided the basis for the development of a motivational scale which included five sub-scales: social support and affirmation; social life and the value of playing an instrument; enjoyment of performing; self-belief in musical ability; and enjoyment of instrumental musical activities. There were linear trends for each of the five sub-scales in relation to level of expertise with the exception of social support and affirmation. The five sub-scales collectively predicted a composite score relating to aspirations with a multiple $r$ of .64 .
\end{abstract}

Keywords Motivation, music, instruments, aspirations, expertise, development

\section{Introduction}

Human motivation is complex. Recent reviews of research on musical motivation have acknowledged this. Models have been developed which recognise the interactions which occur between environmental (cultural, institutional, familial and educational) and internal factors (cognition and affect) enhancing or reducing motivation (see Asmus 1994; Austin, Renwick \& McPherson, 2006; Evans, McPherson \& Davidson, 2013; Hallam, 2002; 2016; O'Neill \& McPherson, 2002; Sichivitsa, 2007). Four main motivational themes have emerged from previous research: satisfying personal needs; developing and maintaining a positive musical identity; acquiring effective approaches to learning music; and having a supportive environment. The balance between these motives changes over time as individuals progress 
through their musical careers (Harnischmacher 1997; Manturzewska 1990; Sosniak 1985). These changes may contribute to determining individual career trajectories. The research reported here aimed to explore whether changes occurred in the relative importance of a range of motivational elements as expertise developed in school aged children and the extent to which different aspects of motivation predicted long term aspirations relating to music.

\section{Satisfying personal needs}

Musicians derive considerable personal fulfilment from the act of making music. Music can meet emotional and hedonistic needs (Asmus \&Harrison; 1990; Gellrich, Osterwold \& Schulz, 1986; Martin, 2008; Nagel, 1987; O’Neill, 1999; Persson, Pratt \& Robson, 1996; Pitts, Davidson \& McPherson, 2000a).It can also fulfil needs for achievement, curiosity and self-actualisation (Chaffin and Lemieux, 2004; Gellrich et al., 1986); Motte-Haber, 1984; Persson et al., 1996) and lead to satisfaction derived from positive social responses to successful playing and performance (Nagel, 1987; Persson et al., 1996). Music also provides opportunities for demonstrating autonomy as the individual determines the level and nature of engagement with music (Austin et al., 2006; Burland \& Davidson, 2004; Creech, Papageorgi, Duffy, Morton, Hadden, Potter, De Bezenac, Whyton, Himonides \& Welch, 2008; MacNamara, Holmes \& Collins, 2006).

\section{Developing and maintaining a positive musical identity}

Having a positive musical identity makes a major contribution to musical motivation (Austin 1991; Austin \& Vispoel 1992; Eccles, O’Neill \& Wigfield, 2005; Martin, 2008; Wigfield, Eccles, Yoon, Harold, Arbreton, Freedman-Doan \& Blumenfield, 1997). It is important to maintain positive self-belief over time (Creech et al., 2008; Creech, 2009; Long, Gaunt, Creech \& Hallam, 2010; MacNamara et al., 2006) and sustain musical self-efficacy (McPherson \& McCormick, 1999; 2000; 2006). Young musicians also need to demonstrate resilience when faced with negative feedback (Duke \& Henninger, 1998) and develop the capacity to manage strong feelings and impulses (Werner, 1995). Actively making music also provides the opportunity to set high standards and achieve them (Burland \& Davidson, 2004; Creech et al., 2008; MacNamara et al., 2006). Self-efficacy in relation to musical goals has been found to be the best predictor of instrumental examination results (McPherson \& McCormick,1999; 2006). Having a positive musical self-concept is also related to high levels of attainment and successful task performance (Asmus \& Harrison, 1990; Vispoel, 1993), motivation for engaging with music, interest in it, and commitment to continue playing (Klinedinst, 1991). Those who give up playing tend to have lower expectations of success (Chandler, Chiarella \& Auria, 1988; Pitts, Davidson \& McPherson, 2000b) and are less confident about future outcomes largely because of unsuccessful earlier experiences (StGeorge, 2010).

\section{Acquiring effective approaches to learning music}

The adoption of mastery learning goals (a focus on constant improvement, the desire to learn new skills, master new tasks or understand new things) (Chaffin and Lemieux, 2004; Martin, 2008; Schmidt, 2005; Smith, 2005) is important in supporting motivation to learn. Autonomy in choice of repertoire also makes a contribution to enhancing motivation (Renwick \& McPherson, 2002), as does the extent to which students value what they are doing (O'Neill, 1999b). However, research comparing the importance of mastery as opposed to performance goals in music has had mixed results (Austin, 1988; 1991; Lacaille, Koestner \& Gaudreau, 
2007; Sandene, 1998; Schmidt, 2005). Overall, the way in which active participation in music is enacted seems to influence whether mastery or performance goals are adopted. Some enactments support the development of both types. However, to succeed in music clearly requires mastery behaviour to sustain motivation for practice (O’Neill, 1997). To maintain positive self-beliefs the goals set for mastery need to be realistic (Burland \& Davidson, 2004; Creech et al., 2008; Coulson, 2010; MacNamara et al., 2006).

To sustain motivation, appropriate attribution strategies to explain success and failure need to be adopted. Most effective are those which focus on effort, practice and strategy use (Asmus 1986a , 1968b; McPherson \& McCormick,1999; Vispoel \& Austin,1993;). Overall, in music, attributions tend to be made regarding effort, musical background, classroom environment, musical ability and love of music (Arnold, 1997; Asmus, 1986a; 1968b; 1989; Legette, 1998). Findings specifically related to performance in an examination have included effort in preparation, effort in the examination, nervousness, luck, and task difficulty (McPherson \& McCormick, 2000). Highly motivated students tend to make effort attributions, while students with low motivation cite ability (Asmus, 1986a, 1986b; Austin \& Vispoel 1998; McPherson \& McCormick 2000). Ability attributions seem to become more frequent as children get older (Arnold 1997; Asmus 1986a, 1968b). Beliefs, about the nature of musical ability, whether learners believe that musical ability can be enhanced rather than being fixed (incremental beliefs) are important insofar as those holding such beliefs tend to have more effective practice habits and higher attainment (Braten \& Stromso, 2004).

Being able to practice effectively may contribute to motivation enhancement (Hallam, Rinta,Varvarigou, Creech, Papageorgi \& Lani, 2012; Jorgensen, 2004; Jorgensen \& Hallam, 2009; Manturzewska 1990; McPherson \& Renwick, 2001; McPherson \& Zimmerman, 2002). Effective practice is implicated in flow states (O’Neill, 1999) which represent a state of equilibrium between the amount of challenge in activities and an individual's capabilities leading to perceived enjoyment (Csikszentmihalyi, 1991).

\section{Having a supportive environment}

Social interactions are an acknowledged source of influence on students' motivation to engage in active music making (Creech and Hallam, 2003; Creech, 2008; Davidson, Howe, Moore \& Sloboda,1996). The support of family, friends and colleagues is particularly important (Austin \& Vispoel, 1998; Burland \& Davidson, 2002; Creech, et al., 2008; Creech, 2009; Creech \& Hallam, 2011; Davidson et al, 1996; Howe \& Sloboda, 1991; Legette, 2003; MacNamara et al., 2006; Moore, Burland \& Davidson, 2003; Patrick, Ryan, Alfred-Liro, Fredricks, Hruda \& Eccles, 1999; Zdzinski, 2013). Families who have musical skills and are interested in music seem to be able to transfer these values and interests to their children (Moore et al., 2003; Pitts et al., 2000a; Zdinski, 1996). Where parents are indifferent or less involved, children are more likely to give up playing (Davidson et al., 1996; O'Neill, 2002; Pitts et al., 2000a).

The support of excellent teachers is also crucial in motivating learners (Asmus, 1989; Creech and Hallam, 2011; Davidson et al., 1996; 1998; Duke, Flowers \& Wolfe 1997; Lamont 2002; Sloboda \& Howe 1991; Sosniak 1985; Szubertowska, 2005). Teachers are particularly important as role models (Manturzewska, 1990). The relationship between pupil and teacher, the sensitivity of the communication between them and the extent to which the student has a sense of autonomy all have an impact on learners' love of music (Bakker, 2005; Cassie, 2008; StGeorge, 2010). Pupils who give up playing have had poorer relationships with their 
teachers than their peers (StGeorge, 2010). The environment within which the teacher is working can also exert an influence. A positive, supportive institutional ethos can make a valuable contribution to enhancing motivation (Jorgensen 1997; Papageorgi, Haddon, Creech, Morton, de Bezenac, Himonides, Potter, Duffy, Whyton \& Welch, 2010).

In adolescence, the peer group is very powerful and can bring negative pressure to bear in relation to engagement with some types of music (Finnas 1987; 1989). It can also have an impact on whether students continue to play an instrument or not (Allen, 1981). Young people involved in the arts more generally are appreciative of the support they receive from their peers (Burland \& Davidson, 2004; O’Neill, 2002; Patrick et al., 1999), although Hallam (1998) found that perceptions of peer influence were less predictive of commitment to practice than children's own attitudes towards playing.

While support from family, friends and teachers is clearly important in enhancing motivation there is evidence that those who cease to play an instrument tend to engage in more teacher approval seeking behaviour (Costa-Gioma, Flowers \& Sasake, 2005; McPherson \& Renwick, 2001). Some students refer to participation in band, or the opinions of their parents and friends as crucial in shaping their own attitudes towards music (Pitts et al., 2000a; 200b). It may be that motivation needs to be intrinsic for long term commitment to music to be made.

\section{Differences in motivation and aspirations}

There are considerable differences in the level of commitment that individuals make to music. For many children playing an instrument is viewed no differently from other activities which they undertake in their free time (McPherson \& McCormick, 2000). For some however, career planning is in evidence in the very earliest stages of learning to play an instrument along with dedication, commitment, determination and a willingness to make sacrifices (MacNamara et al., 2006). Indeed, Kemp (1996) found that the most accomplished classical musicians in his sample were self-motivated almost to the point of obsession.

There has been little previous work focusing on which motivational factors best predict musical aspirations. Hallam (2013) working with a relatively small sample found that overall the best predictor of musical aspirations was enjoying musical activities. This included listening to music, going to concerts, playing in musical groups, and having an active social life relating to music. Also important were the support of family, friends, and teachers; and self-beliefs. Practising strategies emerged as contributing for those wanting to become musicians. The current study, involving a large sample, aims to build on this initial work exploring whether and how various motivational influences change as expertise develops in school aged students and which best predict longer term musical aspirations.

\section{Method}

The present study adopted a self-report questionnaire as a means of collecting data from a large sample of learners. The questionnaire was devised based on the research evidence outlined above and a smaller scale prior study (Hallam, 2013). The questionnaire sought information about the level of expertise attained as assessed by the highest examination grade achieved in independent graded instrumental examinations from preliminary to Grade 8 . Typically, graded examinations assess candidates' performance on pieces, scales, sightreading, and aural tests. Examinations are taken when the teacher believes that the student is ready. They are not age related and can be taken by adults. As such they provide a 
convenient, widely recognised and impartial means of assessing level of expertise. The questionnaire included a range of statements relating to various elements of motivation including support of family and friends; the respondents' enjoyment of participating in performance; enjoying playing an instrument and having lessons; listening to music; music as a social activity; enjoyment of practice; self-beliefs about musical ability and potential; beliefs about self-efficacy and the relationship between effort and musical ability; and social affirmation. Respondents were requested to respond to the statements on a 7 point Likert scale with 7 indicating the strongest agreement, 1 the strongest disagreement. There were 3 statements relating to musical aspirations: to always want to engage with music; wanting to be a musician; and perceiving that playing an instrument would be useful to any future career. The questionnaire was piloted on a small group of young musicians to ensure that the statements were easy to understand. Their feedback indicated that no changes were required.

\section{Respondents}

Data were collected by a team of researchers from young people playing all of the classical and popular musical instruments in a variety of settings including two junior conservatoires, two Local Authority youth orchestras, two Local Authority Saturday music schools, a conservatoire for popular music and three state comprehensive schools. The children who participated were receiving tuition on their instruments individually or in small groups of no more than four children. The organisations which the children were attending were approached and permission requested for questionnaires to be administered.

A total of 3325 children and young people ranging in level of expertise from beginner through to Grade 8 level (minimum required for conservatoire entrance in the UK) participated in the research facilitating the identification of 9 levels of expertise. The age range was from 6 to 19 years. Table 1 describes the relationship between level of expertise and age with the minimum and maximum age at each level of expertise. The wide age range at each level reflects the fact that the examinations are independent of school systems and can be taken at any age. The instruments that participants played were representative of the classical and popular instruments played in the UK. The greatest number played the violin (28\%) followed by flute (10\%), piano (10\%), clarinet (10\%), cello $(8 \%)$, trumpet $(6 \%)$, guitar $(4 \%)$, viola $(3 \%)$, voice $(3 \%)$, saxophone $(3 \%)$, French horn $(3 \%)$, trombone $(3 \%)$, oboe $(2 \%)$, drums $(2 \%)$, double bass $(2 \%)$, percussion $(1 \%)$, cornet $(1 \%)$, tuba $(1 \%)$, recorder $(1 \%)$, bassoon $(1 \%)$, harp $(1 \%)$ with other instruments played by fewer than one percent of respondents.

Table 1: Age by level of expertise

\begin{tabular}{|c|c|c|c|c|c|}
\hline \multicolumn{6}{|c|}{ Age in years } \\
\hline Level of expertise & Mean & $\mathrm{N}$ & Std. Deviation & Minimum & Maximum \\
\hline $\begin{array}{l}\text { Preliminary } \\
\text { grade }\end{array}$ & 11.45 & 489 & 2.77 & 5 years & 18 years \\
\hline Grade 1 & 11.13 & 283 & 1.98 & 7 years & 18 years \\
\hline Grade 2 & 11.88 & 196 & 2.11 & 7 years & 18 years \\
\hline Grade 3 & 12.49 & 249 & 2.08 & 7 years & 19 years \\
\hline Grade 4 & 13.09 & 239 & 1.83 & 6 years & 18 years \\
\hline Grade 5 & 14.12 & 491 & 1.89 & 9 years & 18 years \\
\hline Grade 6 & 14.59 & 295 & 1.94 & 8 years & 18 years \\
\hline Grade 7 & 15.17 & 266 & 1.70 & 10 years & 19 years \\
\hline Grade 8 & 16.10 & 347 & 1.65 & 10 years & 19 years \\
\hline Total & 13.37 & 2855 & 2.66 & 5 years & 19 years \\
\hline
\end{tabular}




\section{Procedure}

The research was designed taking account of the ethical guidelines of the British Psychological Society and the British Educational Research Association and was approved by the ethics committee of the Institute of Education, University College London. The researchers administered the questionnaires to students in the various learning environments. The exact procedures for this varied depending on the environment.

\section{Results}

\section{Exploratory Factor analysis}

As a first step in the analysis, exploratory factor analysis was undertaken as a means of establishing the relationships between the variables. All of the variables were entered except those relating to aspirations. A Principal Components analysis was selected as it affords an empirical analysis of the data set (Tabachnick \& Fidell, 2001). A varimax rotation was used to enable interpretation and description of results (Tabachnick \& Fidell, 2001). Two checks were made to assess sampling adequacy, the Kaiser-Meyer-Olkin (KMO) test (checks whether the sample is large enough to carry out factor analysis) and an anti-matrix of covariances and correlations which showed that all elements on the diagonal of these matrices were greater than -.5 , the necessary requirement. The KMO was 0.916 greater than the 0.5 required to assess the adequacy of the sample (Field, 2009).

Decisions about the numbers of factors to be retained in any exploratory factor analysis depend on a range of criteria (Abell, Springer and Kamata, 2009). The Kaiser criterion suggests that eigenvalues above 1 should determine the number of factors (Guttman, 1954; Kaiser, 1960). However, Jollife $(1972,1986)$ suggests retaining factors with eigenvalues of more than 0.7. Sample size is also important. Stevens (2002) suggests that for samples of over 1000 factor loadings are significant if they exceed 0.162. Recently, these criteria have been questioned and ways suggested of establishing whether eigenvalues of 1 are valid (see O'Conner, 2000). Another approach to deciding on the number of factors is the use of a scree plot (Cattell, 1966). Parallel analysis, which is based on the principle that a factor to be extracted should account for more variance than is expected by chance, can also be used (Horn, 1965). In addition, the decision about the number of factors can be based on subjective judgement either a priori or post hoc (Abell et al., 2009). A further consideration is that greater variance can be explained when a greater number of factors are included (Tabachnick and Fidell, 2001). As Abell et al. (2009) argue 'there is no magic formula to determine the correct number of latent factors' (p144).

The purpose of the research reported here was to explore how the different elements of motivation might change as expertise developed and also relate any changes to musical aspirations. It was therefore important that the factors derived distinguished between different elements of motivation. The identified factors would then form the basis for the development of a motivation scale. Taking this into account, eigenvalues were retained if they were greater than 1. A scree plot was also used to identify those factors before the breaking point of the elbow of the plot. Following examination of the scree plot a 6 factor solution seemed to be the most appropriate. As the number of components with eigenvalues greater than 1 is usually somewhere between the number of variables divided by 3 and the number divided by 5 between 8 and 5 factors might have been expected (Tabachnick \& Fidell, 2001). This 
supported a 6 factor solution. Some authors have suggested that a range of possible factor solutions may be tried (Tabachnich \& Fidell, 2001). To explore if a more parsimonious solution was possible a 5 factor solution was explored. The factors resulting from this analysis did not provide a theoretically meaningful outcome which could be related to the previous literature. It was therefore concluded that a 6 factor solution provided the most appropriate basis from which to develop a motivation scale. Together the 6 factors accounted for $59 \%$ of the variance. Table 2 sets out the weightings for each variable. Weightings below 0.2 are not included.

A further challenge in factor analysis is to name the derived factors. Comrey and Lee (1992) provide guidance as to which variables should be taken into account in this process. They suggest that factor loadings of .71 are excellent, .63 very good, .55 good, .45 fair and .32 poor. Taking account of this, only weightings of above .45 were considered in the conceptualisation of each factor. These are described below. 
Table 2: Standardised beta weightings for each statement in relation to the six factors

\begin{tabular}{|c|c|c|c|c|c|c|}
\hline \multicolumn{7}{|c|}{ Rotated Component Matrix } \\
\hline & $\begin{array}{l}\text { Factor } 1 \\
\text { Social } \\
\text { support and } \\
\text { affirmation }\end{array}$ & $\begin{array}{l}\text { Factor } 2 \\
\text { Social life } \\
\text { and the } \\
\text { value of } \\
\text { playing an } \\
\text { instrument }\end{array}$ & $\begin{array}{l}\text { Factor } 3 \\
\text { Enjoyment } \\
\text { of } \\
\text { performing }\end{array}$ & $\begin{array}{l}\text { Factor } 4 \\
\text { Self-belief } \\
\text { in musical } \\
\text { ability }\end{array}$ & $\begin{array}{l}\text { Factor } 5 \\
\text { Enjoyment } \\
\text { of playing } \\
\text { and lessons }\end{array}$ & $\begin{array}{l}\text { Factor } 6 \\
\text { Disliking } \\
\text { practice }\end{array}$ \\
\hline Playing in concerts gives me a real thrill & & & .83 & & & \\
\hline I like practising & & & .26 & .27 & & -.66 \\
\hline $\begin{array}{l}\text { My teachers at school like me to play a musical } \\
\text { instrument }\end{array}$ & .49 & & .31 & & & \\
\hline I enjoy playing my instrument very much & .37 & .28 & .34 & .25 & .33 & -.23 \\
\hline $\begin{array}{l}\text { I can achieve anything I want on my instrument if I } \\
\text { practise enough }\end{array}$ & .54 & & .25 & .37 & & \\
\hline My parents want me to play an instrument & .74 & & & & & \\
\hline Most people think that I play my instrument well & .64 & & .23 & .33 & & \\
\hline I find it very satisfying to play in concerts & .24 & .24 & .79 & & & \\
\hline $\begin{array}{l}\text { I am usually successful in what I attempt to do on my } \\
\text { instrument }\end{array}$ & .42 & & .36 & .49 & & \\
\hline I enjoy listening to music & .29 & .37 & & .23 & .21 & \\
\hline $\begin{array}{l}\text { To succeed playing an instrument you need musical } \\
\text { ability }\end{array}$ & & & & .74 & & \\
\hline I have musical ability & .28 & & & .64 & .25 & \\
\hline On some days I don't want to practise & & & & & & .73 \\
\hline $\begin{array}{l}\text { Playing an instrument is an important part of my } \\
\text { social life }\end{array}$ & & .54 & .29 & .28 & & \\
\hline I have the potential to be a good musician & .33 & .26 & & .56 & & \\
\hline I enjoy going to concerts to listen & & .61 & .29 & .25 & & \\
\hline I think it is valuable to play a musical instrument & .25 & .59 & & .25 & .29 & \\
\hline I have a lot of friends who play musical instruments & & .72 & & & & \\
\hline $\begin{array}{l}\text { I enjoy playing in musical groups, orchestras and } \\
\text { bands }\end{array}$ & & .44 & .42 & & .45 & \\
\hline I find practising boring & & & & & -.56 & .64 \\
\hline I enjoy my instrumental lessons & & & & & .72 & \\
\hline I hate having to play a musical instrument & & & & & -.84 & \\
\hline $\begin{array}{l}\text { My brothers/sisters like me playing a musical } \\
\text { instrument }\end{array}$ & .46 & .46 & & & & -.20 \\
\hline $\begin{array}{l}\text { My relations (for example grandparents, aunts and } \\
\text { uncles) like me playing a musical instrument }\end{array}$ & 67 & .37 & & & & \\
\hline
\end{tabular}

NB Items with weightings below 0.2 have been omitted from the table

Factor 1: Social support and affirmation: Factor 1 had an eigenvalue of 7.3 and explained $30.47 \%$ of the variance. This factor had high weightings for parents (.74), relatives (.66), teachers (.49), and brothers and sisters (.46) wanting the participant to play an instrument and most people thinking that they played their instrument well (.63).

Factor 2: Social life and the value of playing an instrument: Factor two had an eigenvalue of 1.91 accounting for $7.95 \%$ of the variance. This factor had high weightings for having lots of friends who played musical instruments (.72), enjoying going to concerts to listen (.61), believing it was valuable to play a musical instrument (.59), playing an instrument being an important part of participants' social life (.55) and brothers and sisters liking them playing a musical instrument (.46). .

Factor 3: Enjoyment of performing: Factor 3 had an eigenvalue of 1.43 accounting for $5.97 \%$ of the variance. This factor had high weightings for statements relating to finding it very satisfying to play in concerts (.79) and playing in concerts giving participants a real thrill (.83). 
Factor 4: Self-belief in musical ability: Factor 4 had an eigenvalue of 1.25 accounting for $5.19 \%$ of the variance. This factor focused on self-beliefs with high weightings for statements relating to needing musical ability to succeed in playing an instrument (.74), participants having musical ability (.64), having the potential to be a good musician (.56) and participants usually being successful in what they attempted to do on their instrument (.49).

Factor 5: Enjoyment of instrumental musical activities: Factor 5 had an eigenvalue of 1.03 accounting for $4.31 \%$ of the variance. This factor had high negative weightings for hating having to play an instrument (-.84) and finding practice boring (-.56) and positive weightings for enjoying instrumental lessons (.72) and enjoying playing in musical groups (.45).

Factor 6: Disliking practice: Factor 6 had an eigenvalue of 1.01 accounting for $4.2 \%$ of the variance. This factor had high weightings for not wanting to practice on some days (.73), finding practice boring (.64) and a negative weighting for liking practice (-.66).

\section{Scale development}

The factor analysis provided the basis for the development of a motivation scale for instrumental music. In developing the scale items with weightings of less than .45 were excluded. Cronbach Alphas were calculated for the items in each identified factor. Items were removed if that led to an increase in the Cronbach Alpha. Examination of the Rotated Component Matrix revealed that two items had weightings of above .45 on more than one factor. These items were 'My brothers/sisters like me playing a musical instrument' and 'I find practising boring'. To establish whether these items should be included in the scale and if so in which sub-scales, Cronbach Alphas were calculated to establish the most appropriate sub-scale. These analyses led to the item relating to brothers and sisters support being dropped as it did not increase the Cronbach Alpha for either possible sub-scale. When the item 'I find practising boring' was included in the sub-scale 'enjoyment of instrumental musical activities' it increased the Cronbach Alpha considerably. Further analyses of the Cronbach Alpha's of the items relating to Factors 5 and 6 indicated that the most parsimonious sub-scale was obtained by including items from both of these factors creating a single subscale. This sub-scale included items relating to the enjoyment of a variety of instrumental musical activities. The statements included in the final version of the scale and the relevant Cronbach Alphas are set out in Table 3. Each of the subscales has a Cronbach Alpha greater than .7 which is considered acceptable (Abell et al., 2009; Kline 1999) particularly as the number of items in each sub-scale is small (Field, 2009). The final scale comprised 18 items with 5 sub-scales: social support and affirmation (5 items); social life and the value of playing an instrument (4 items); enjoyment of performing ( 2 items); selfbelief in musical ability ( 3 items) and enjoyment of instrumental musical activities (4 items) The Cronbach Alpha for the whole scale was .86. 
Table 3: Subscale statements and Cronbach Alphas

\begin{tabular}{|c|c|c|}
\hline Sub-section of scale & Statements & $\begin{array}{l}\text { Cronbach } \\
\text { Alpha }\end{array}$ \\
\hline Social support and affirmation & $\begin{array}{l}\text { My teachers at school like me to play a musical instrument } \\
\text { I can achieve anything I want on my instrument if I practise enough } \\
\text { Most people think that I play my instrument well } \\
\text { My parents want me to play an instrument } \\
\text { My relations (for example grandparents, aunts and uncles) like me } \\
\text { playing a musical instrument }\end{array}$ & .74 \\
\hline $\begin{array}{l}\text { Social life and the value of playing } \\
\text { an instrument }\end{array}$ & $\begin{array}{l}\text { Playing an instrument is an important part of my social life } \\
\text { I enjoy going to concerts to listen } \\
\text { I think it is valuable to play a musical instrument } \\
\text { I have a lot of friends who play musical instruments }\end{array}$ & .71 \\
\hline Enjoyment of performing & $\begin{array}{l}\text { Playing in concerts gives me a real thrill } \\
\text { I find it very satisfying to play in concerts }\end{array}$ & .78 \\
\hline Self-belief in musical ability & $\begin{array}{l}\text { I have the potential to be a good musician } \\
\text { I have musical ability } \\
\text { I am usually successful in what I attempt to do on my instrument }\end{array}$ & .72 \\
\hline $\begin{array}{l}\text { Enjoyment of instrumental musical } \\
\text { activities }\end{array}$ & $\begin{array}{l}\text { I hate having to play a musical instrument (reversed) } \\
\text { I find practice boring (reversed) } \\
\text { I enjoy my instrumental lessons } \\
\text { I enjoy playing in musical groups, orchestras and bands }\end{array}$ & .72 \\
\hline
\end{tabular}

Relationships between elements of the scale and level of expertise

Analysis of variance was undertaken for each sub-section of the scale by level of expertise also taking account of whether the relationship was linear. These analyses are set out below.

Social support and affirmation: There was a statistically significant relationship between the sub-scale support and social affirmation and level of expertise $(\mathrm{F}(8,2776)=3.72, \mathrm{p}=$ $.0001, \eta p 2=.012$ ). There was no statistically linear relationship between level of expertise and social support and affirmation. The means by level of expertise are set out in Table 4 and Figure 1.

Social life and the value of playing an instrument: There was a statistically significant relationship between social life and the value of playing an instrument and level of expertise $(\mathrm{F}(8,2808)=31.76, \mathrm{p}=.0001, \eta \mathrm{p} 2=.08)$ and a statistically significant linear relationship $(\mathrm{F}(1,8)=186.68, \mathrm{p}=.0001)$. The means by level of expertise are set out in Table 4 and Figure 2.

Enjoyment of performing: There was a statistically significant relationship between Enjoyment of performing and level of expertise $(F(8,2829)=26.7, p=.0001, \eta p 2=06)$ and a statistically significant linear relationship $(\mathrm{F}(1.8)=134.9, \mathrm{p}=.0001)$. Table 4 and Figure 3 set out the means by level of expertise.

Self-belief in musical ability: There was a statistically significant relationship between selfbelief and level of expertise $(F(8,2817)=9.44, p=.0001, \eta p 2=.02)$ and a statistically significant linear trend $(F(1,8)=46.78, p=p .0001)$. Table 4 and Figure 4 set out the means by level of expertise.

Enjoyment of instrumental musical activities: There was a statistically significant relationship between enjoyment of instrumental musical activities and level of expertise $(\mathrm{F}(8.2714)=15.63, \mathrm{p}=.0001, \eta \mathrm{p} 2=.04)$ and a statistically significant linear relationship $(\mathrm{F}(1,8)=13.26, \mathrm{p}=.0001)$. Table 4 and Figure 5 set out the means by level of expertise. 
The motivation scale: There was a statistically significant relationship between the whole motivation scale and level of expertise $(\mathrm{F}(8,2601)=19.63, \mathrm{p}=.0001, \eta \mathrm{p} 2=.057)$ and a statistically significant linear relationship $(F(1,8)=82.67, p=.0001)$. Table 4 and Figure 6 set out the means by level of expertise.

Table 4: Means, standard deviations, minimum and maximum scores of sub-scales by level of expertise

\begin{tabular}{|c|c|c|c|c|c|}
\hline & $\mathrm{N}$ & Mean & $\begin{array}{c}\text { Std. } \\
\text { Deviation } \\
\end{array}$ & Minimum & Maximum \\
\hline \multicolumn{6}{|c|}{ Social support and affirmation } \\
\hline Preliminary & 483 & 27.00 & 5.67 & 0 & 35.00 \\
\hline Grade 1 & 280 & 28.53 & 5.70 & 0 & 35.00 \\
\hline Grade 2 & 187 & 28.59 & 4.75 & 0 & 35.00 \\
\hline Grade 3 & 244 & 27.62 & 4.88 & 10 & 35.00 \\
\hline Grade 4 & 236 & 27.57 & 4.52 & 11 & 35.00 \\
\hline Grade 5 & 471 & 27.86 & 4.36 & 8 & 35.00 \\
\hline Grade 6 & 283 & 27.39 & 3.96 & 13 & 35.00 \\
\hline Grade 7 & 259 & 27.99 & 3.91 & 20 & 35.00 \\
\hline Grade 8 & 342 & 28.03 & 4.14 & 12 & 35.00 \\
\hline Total & 2785 & 27.77 & 4.76 & 0 & 35.00 \\
\hline \multicolumn{6}{|c|}{ Social life and the value of playing an instrument } \\
\hline Preliminary & 488 & 19.91 & 5.15 & 0 & 28.00 \\
\hline Grade 1 & 277 & 20.69 & 4.99 & 0 & 28.00 \\
\hline Grade 2 & 184 & 20.52 & 4.32 & 0 & 28.00 \\
\hline Grade 3 & 249 & 20.69 & 4.14 & 7 & 28.00 \\
\hline Grade 4 & 243 & 20.13 & 4.39 & 4 & 28.00 \\
\hline Grade 5 & 481 & 21.86 & 3.96 & 1 & 28.00 \\
\hline Grade 6 & 288 & 21.69 & 4.23 & 0 & 28.00 \\
\hline Grade 7 & 257 & 22.56 & 3.50 & 10 & 28.00 \\
\hline Grade 8 & 350 & 23.97 & 3.28 & 12 & 28.00 \\
\hline Total & 2817 & 21.38 & 4.47 & 0 & 28.00 \\
\hline \multicolumn{6}{|c|}{ Enjoyment of performing } \\
\hline Preliminary & 490 & 9.33 & 3.58 & 0 & 14.00 \\
\hline Grade 1 & 282 & 10.22 & 3.03 & 0 & 14.00 \\
\hline Grade 2 & 189 & 10.88 & 2.58 & 0 & 14.00 \\
\hline Grade 3 & 249 & 10.21 & 2.81 & 2 & 14.00 \\
\hline Grade 4 & 241 & 10.09 & 2.68 & 2 & 14.00 \\
\hline Grade 5 & 483 & 10.84 & 2.44 & 0 & 14.00 \\
\hline Grade 6 & 287 & 10.83 & 2.38779 & 2 & 14.00 \\
\hline Grade 7 & 265 & 11.51 & 2.08367 & 3 & 14.00 \\
\hline Grade 8 & 352 & 11.66 & 2.22867 & 2 & 14.00 \\
\hline Total & 2838 & 10.57 & 2.83250 & 0 & 14.00 \\
\hline \multicolumn{6}{|c|}{ Self-belief in musical ability } \\
\hline Preliminary & 488 & 15.19 & 3.66 & 0 & 21.00 \\
\hline Grade 1 & 277 & 15.88 & 3.68 & 0 & 21.00 \\
\hline Grade 2 & 187 & 15.77 & 3.32 & 0 & 21.00 \\
\hline Grade 3 & 248 & 15.71 & 2.82 & 7 & 21.00 \\
\hline Grade 4 & 243 & 15.46 & 3.07 & 5 & 21.00 \\
\hline
\end{tabular}




\begin{tabular}{lccccc}
\hline Grade 5 & 483 & 16.31 & 2.86 & 5 & 21.00 \\
Grade 6 & 287 & 16.04 & 2.62 & 6 & 21.00 \\
Grade 7 & 264 & 16.46 & 2.68 & 9 & 21.00 \\
Grade 8 & 349 & 16.76 & 2.69 & 5 & 21.00 \\
Total & 2826 & 15.96 & 3.12 & 0 & 21.00
\end{tabular}

Enjoyment of instrumental music activities

\begin{tabular}{lccccc}
\hline Preliminary & 444 & 19.51 & 5.52 & 4 & 28.00 \\
Grade 1 & 270 & 20.90 & 5.42 & 4 & 28.00 \\
Grade 2 & 181 & 20.33 & 5.15 & 4 & 28.00 \\
Grade 3 & 245 & 20.04 & 4.94 & 4 & 28.00 \\
Grade 4 & 240 & 20.21 & 4.49 & 4 & 28.00 \\
Grade 5 & 467 & 21.32 & 4.44 & 5 & 28.00 \\
Grade 6 & 282 & 20.94 & 4.62 & 4 & 28.00 \\
Grade 7 & 252 & 21.85 & 4.33 & 5 & 28.00 \\
Grade 8 & 342 & 22.56 & 4.19 & 4 & 28.00 \\
Total & 2723 & 20.87 & 4.89 & 4 & 28.00 \\
& & & & & \\
& & Motivation scale & & \\
Preliminary & 433 & 92.36 & 14.90 & 44 & 126 \\
Grade 1 & 253 & 97.65 & 14.47 & 56 & 126 \\
Grade 2 & 169 & 96.19 & 13.10 & 61 & 124 \\
Grade 3 & 234 & 94.10 & 14.06 & 52 & 126 \\
Grade 4 & 230 & 93.45 & 15.15 & 46 & 126 \\
Grade 5 & 453 & 98.11 & 13.55 & 63 & 126 \\
Grade 6 & 267 & 97.02 & 12.91 & 58 & 124 \\
Grade 7 & 245 & 100.24 & 12.33 & 72 & 126 \\
Grade 8 & 326 & 102.99 & 11.51 & 62 & 126 \\
Total & 2610 & 96.92 & 14.02 & 44 & 126 \\
\hline
\end{tabular}

\section{Figure 1: Social support and affirmation}

\section{Social support and affirmation}

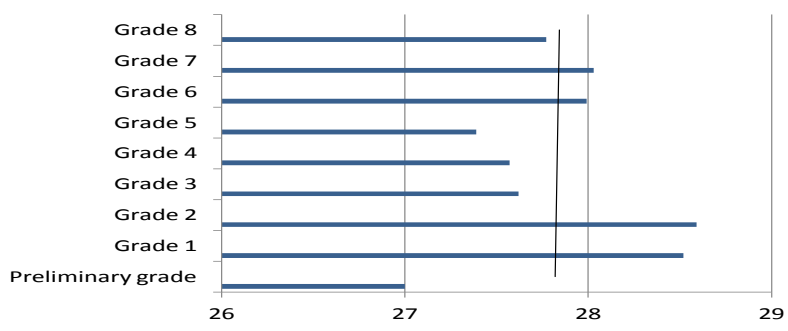


Figure 2: Social life and the value of playing an instrument

Social life and the value of playing an instrument

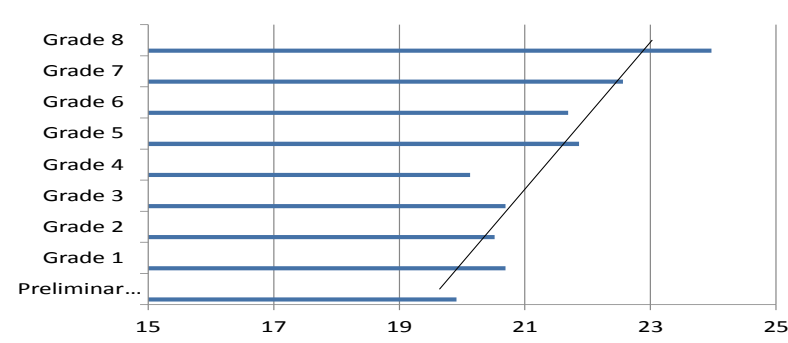

Figure 3: Enjoyment of performing

\section{Enjoyment of performing}

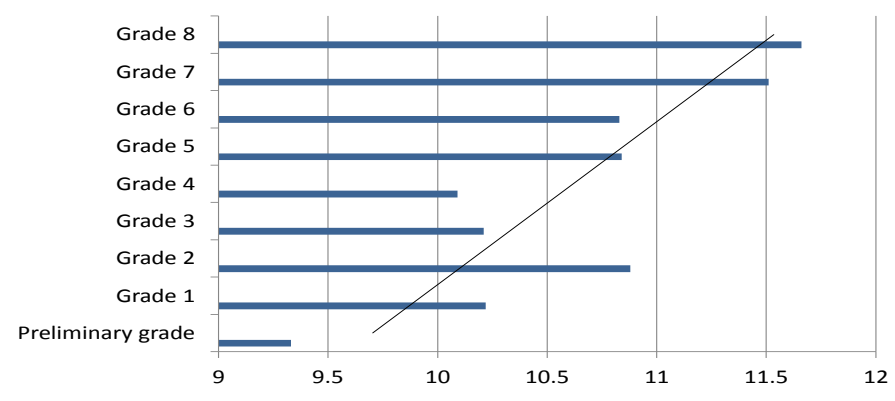

Figure 4: Self-belief in musical ability

\section{Self-belief in musical ability}

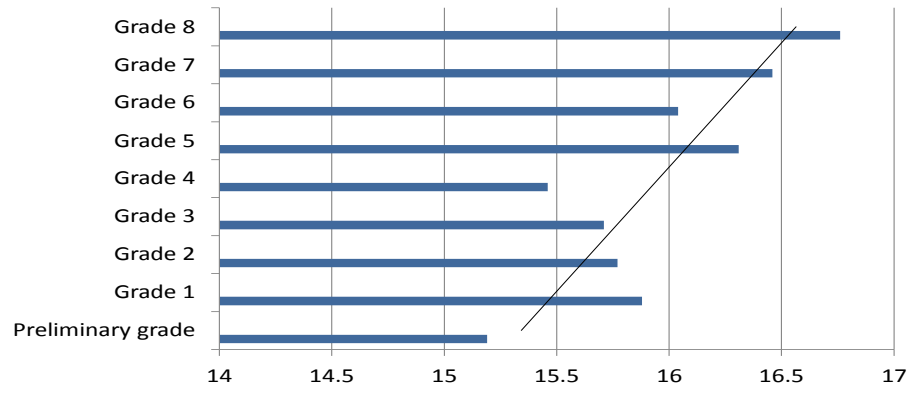


Figure 5: Enjoyment of instrumental musical activities

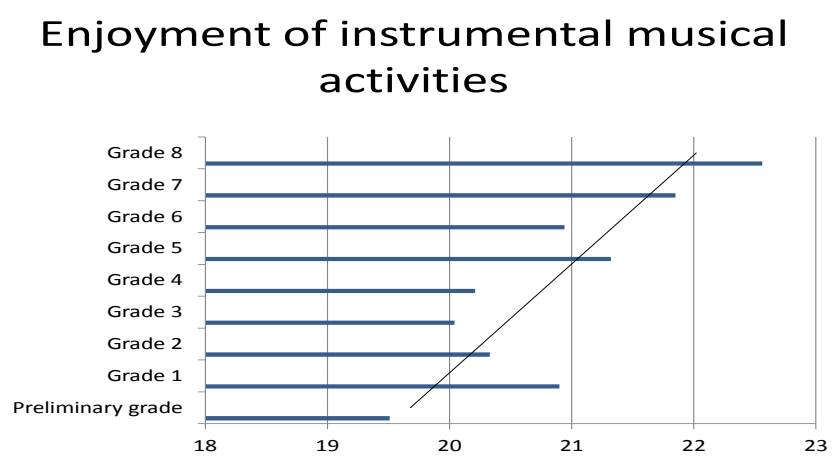

Figure 6: Motivational scale

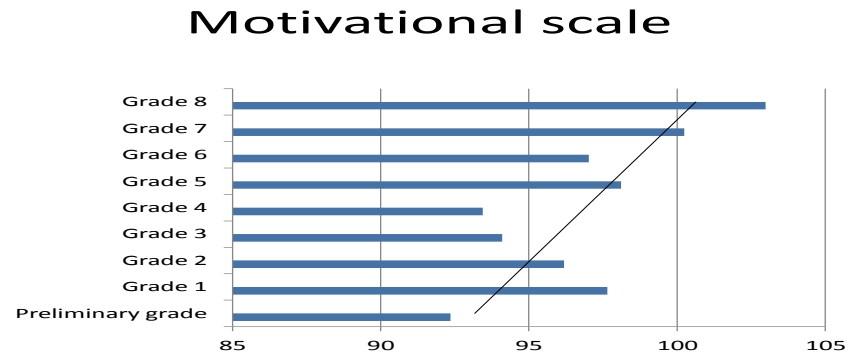

\section{Aspirations}

Three statements measured participants' aspirations: 'I would like to become a musician' (M =4.74); 'I will always want to be involved in musical activities' $(M=5.5)$; and 'I think it will be useful to my future career to play a musical instrument' $(M=5.03)$. These measures were correlated with the correlations ranging from .38 to .55 suggesting that each statement was measuring a slightly different element of motivation.

Correlations with age were very low (.01 and .162 with a negative correlation for being useful to participants' careers being negative (-.01). There were also low correlations between the level of expertise and measures of aspirations (.07 and .11) with the highest $(0.24)$ for being involved in music throughout the lifespan.

An overall aspiration score was calculated by summing the responses to the three separate statements. The means are set out in Table 5. Analysis of variance showed that there was a statistically significant relationship between the level of expertise and the combined aspirational measure $(\mathrm{F}(8,2802)=13.51, \mathrm{p}<.0001, \eta p 2=.034)$ and a statistical significant linear relationship $(\mathrm{F}(8,2802)=77.91, \mathrm{p}<.0001)$. The relationship between this combined score and level of expertise is shown in Figure 7. 
Table 5: Aspirations by level of expertise

\begin{tabular}{lrrrrr}
\hline & & & & & \\
& & \multicolumn{1}{c}{ Mean } & Std. Deviation & Minimum & Maximum \\
\hline Preliminary & 489 & 14.56 & 4.32 & .00 & 21.00 \\
Grade 1 & 281 & 14.80 & 4.34 & .00 & 21.00 \\
Grade 2 & 190 & 14.75 & 3.75 & .00 & 21.00 \\
Grade 3 & 245 & 14.75 & 3.77 & 3.00 & 21.00 \\
Grade 4 & 237 & 14.54 & 3.87 & 3.00 & 21.00 \\
Grade 5 & 477 & 15.64 & 3.81 & 4.00 & 21.00 \\
Grade 6 & 288 & 15.31 & 3.62 & .00 & 21.00 \\
Grade 7 & 260 & 15.72 & 3.62 & 7.00 & 21.00 \\
Grade 8 & 344 & 16.96 & 3.72 & 6.00 & 21.00 \\
Total & 2811 & 15.27 & 3.98 & .00 & 21.00 \\
\hline
\end{tabular}

\section{Figure 7: Aspirations by level of expertise}

\section{Aspirations by level of expertise}

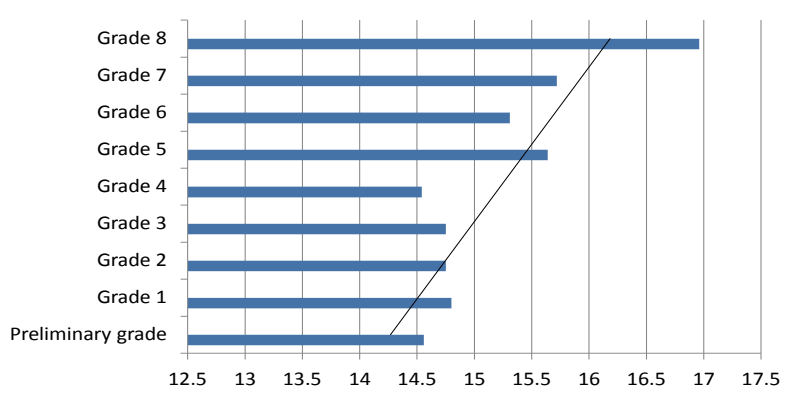

\section{Multiple regression of motivational factors against aspirations}

A series of multiple regression analyses were undertaken exploring the relationships between each aspirational statement and the 6 motivational factors. Table 6 sets out the standardised beta weights for each factor, the Multiple R, R squared, F values and the level of statistical significance. The highest level of prediction for an individual statement was for always wanting to be involved in musical activities $(\mathrm{R}=.61)$. The best predictors of this were social life and the value of playing an instrument, enjoyment of performing, and enjoyment of instrumental music activities. The best predictors for the other aspirational statements were similar, although the weightings differed slightly. When the measures were summed together the overall $\mathrm{R}$ was .64 accounting for $41 \%$ of the variance. The highest weighting was for music being part of the individual's social life (.30). 
Table 6: Subscale weightings for regression analyses on aspirations

\begin{tabular}{|c|c|c|c|c|c|c|c|c|c|}
\hline & $\begin{array}{l}\text { Social } \\
\text { support } \\
\text { and } \\
\text { affirma } \\
\text { tion }\end{array}$ & $\begin{array}{l}\text { Social life } \\
\text { and the value } \\
\text { of playing an } \\
\text { instrument }\end{array}$ & $\begin{array}{l}\text { Enjoy } \\
\text { ment } \\
\text { of } \\
\text { perfor } \\
\text { ming }\end{array}$ & $\begin{array}{l}\text { Self- } \\
\text { belief in } \\
\text { musical } \\
\text { ability }\end{array}$ & $\begin{array}{l}\text { Enjoyment of } \\
\text { instrumental } \\
\text { musical } \\
\text { activities }\end{array}$ & $\mathrm{R}$ & $\begin{array}{l}\text { Adjusted } \\
\mathrm{R} \\
\text { squared }\end{array}$ & $\mathrm{F}$ & SIG \\
\hline $\begin{array}{l}\text { I think it will be useful to my } \\
\text { future career to play a musical } \\
\text { instrument }\end{array}$ & .10 & .16 & .05 & .15 & .23 & .50 & .25 & $\begin{array}{l}196.29 \\
(5,2937)\end{array}$ & .0001 \\
\hline $\begin{array}{l}\text { I will always want to be } \\
\text { involved in musical activities }\end{array}$ & .04 & .32 & .20 & .09 & .15 & .61 & .37 & $\begin{array}{l}342.27 \\
(5,2938)\end{array}$ & .0001 \\
\hline $\begin{array}{l}\text { I would like to become a } \\
\text { musician }\end{array}$ & .10 & .24 & .07 & .19 & -.01 & .48 & .23 & $\begin{array}{l}171.27 \\
(5,2942)\end{array}$ & .0001 \\
\hline Combined aspiration measure & .10 & .30 & .12 & .19 & .15 & .64 & .41 & $\begin{array}{l}409.1 \\
(5,2916)\end{array}$ & .0001 \\
\hline
\end{tabular}

\section{Discussion}

The findings support research which has stressed the importance of social support and affirmation particularly from parents and teachers. This was the only sub-scale which did not show a linear increase in scores as expertise developed. The pattern of scores indicated that students received less support in the earliest stage of learning with an increase at Grades 1 and 2 perhaps as they began to acquire some competence on their instrument (see Figure 1). The perceived level of support then declined between Grades 3 to 5 . Why this might be is not clear and requires further research. The influence of the peer group, which in previous research had been highlighted as important (Allen, 1981; Burland \& Davidson, 2004; O'Neill, 2002; Patrick et al., 1999), was closely related to musical activities being a part of the individual's social life, rather than being linked to social support and affirmation.

There was a linear increase across levels of expertise on the sub-scale that focused on social life and the value of playing an instrument. This supports earlier research which indicated a strong relationship between motivation and the development of a musical identity (Austin 1991; Austin \& Vispoel 1992; Eccles et al., 2005; Martin, 2008; Wigfield et al., 1997). A similar linear pattern emerged with regard to self-belief in musical ability. Much previous research, as indicated in the introduction, showed that maintaining positive self-belief is important in sustaining motivation and that there is a relationship between having a positive musical self-concept and high levels of musical attainment (Asmus \& Harrison, 1990, Vispoel, 1993; McPherson and McCormick, 2006). Levels of success or failure in previous musical performance can affect self-belief (StGeorge, 2010). Where there is repeated success as expertise develops the impact on self-belief is likely to be cumulative.

Enjoyment of performing has previously been relatively neglected in relation to musical motivation. The current findings indicated a linear relationship between level of expertise and the satisfaction derived from performance. Whether this relationship is underpinned by the increased arousal and excitement of the performance itself or the positive feedback from audiences when it is successful (Nagel, 1987; Persson et al., 1996) requires further research. Performance anxiety may also be implicated as the negative impact it can have on performance is likely to affect levels of enjoyment (Papageorgi, Hallam \& Welch, 2007). 
The sub-scale which focused on enjoyment of playing, lessons, making music with others and practice not being boring was not enhanced by the inclusion of the statement 'I like practising'. This suggests that there is a subtle perceived difference between enjoying practice and practice being interesting (not boring). This reflects research findings on the importance of finding a balance between challenge and competence when setting work to be completed, which in turn contributes to achieving a state of flow (Csikszentmihalyi, 1991).

The current research established a linear relationship between aspirations and levels of expertise. Much previous research has shown that as the individual becomes more expert they need to make a greater commitment to music spending more time practising as technical demands increase and the repertoire expands (see Hallam et al., 2012). It is therefore not surprising that there is a relationship between aspirations and level of expertise, either because aspirations drive motivation or because aspirations increase to justify the expended effort. Long term commitment to being involved in musical activities was the aspiration best predicted by the five sub-scales. The strongest predictors were music constituting an element of social life and enjoyment of performance. The sub-scales explained less of the variance in the remaining aspirational variables. The relative weightings of each sub-scale differed for each aspiration suggesting that there are subtle but important motivational differences underpinning each.

While there were strong linear trends for all of the sub-scales except social support and affirmation the linear trends were not perfect. At grades 3 and 4 there was a decline in scores on several of the sub-scales, while the overall motivation scale showed a decline in motivation between Grades 1 and 4. This was reflected to a lesser extent in the overall aspirational measure. The decline in motivation seems to begin between 1 to 3 years after commencing learning (see also Evans et al., 2013). These differences may be related to the effectiveness of practice where similar patterns have been observed (see Hallam et al., 2012).As expertise increases the repertoire becomes more difficult and more systematic practice strategies are required to successfully master it. If learners do not acquire effective strategies they are unlikely to be successful. This may impact on their self-beliefs and their enjoyment of performance which in turn may lead to them giving up playing. While the current research cannot offer conclusive support for this as it was not longitudinal in nature there is considerable evidence that there is much attrition from instrumental music lessons in the first few years of playing (Evans et al., 2013).

Overall, the findings provide a detailed and systematic account of changes in motivation as expertise develops, supporting and elucidating much of the earlier research. They also highlight the complexity of musical motivation, how it can change over time and how different elements contribute with different weightings to different aspirations. Models of musical motivation may need to take greater account of the extent to which musical activity, whether through listening or making music, is pleasurable and satisfies emotional needs. This has been acknowledged by some research, for instance, Asmus and Harrison (1990), Gellrich et al. (1986), Martin (2008), Nagel (1987), O’Neill (1999), Persson et al. (1996) and Pitts et al. (2000a, 2000b) but has not been fully integrated into all motivational models.

There are, of course, limitations to this research as it is based on self-report. As this limitation applies to all of the respondents, however, it is valid to compare responses in the context of developing expertise. A further weakness is that the research is cross sectional, not longitudinal. It therefore cannot be concluded that the observed differences observed in relation to levels of expertise reflect change in individuals over time. This also means that 
conclusions cannot be drawn about the relationship between the different motivational elements and dropout although it is possible to speculate that the observed decreases in some of the sub-scales may lead to dropout.

\section{References}

Abell, N., Springer, D.W. \& Kamata, A. (2009). Developing and validating rapid assessment instruments. Oxford: Oxford University Press.

Allen, B.E. (1981). Student dropout in orchestra programs in three school systems in the state of Arkansas. Unpublished PhD Louisiana, USA: Northeast Louisiana University.

Arnold, J.A. (1997). A comparison of attributions for success and failure in instrumental music among sixth-, eigth- and tenth-grade students. Update: Applications of Research in Music Education, 15(2), 19-23.

Asmus, E.P. (1986a). Achievement motivation characteristics of music education and music therapy students as identified by attribution theory. Bulletin of the Council for Research in Music Education, 86, 71-85.

Asmus E.P. (1986b). Student beliefs about the causes of success or failure in music: A study of achievement motivation. Journal of Research in Music Education, 34, 262-278.

Asmus, E.P. (1989). The effect of music teachers on students' motivation to achieve in music. Canadian Journal of Research in Music Education, 30(1), 14-21.

Asmus, E.P. (1994). Motivation in music teaching and learning. The Quarterly Journal of Music Teaching and Learning, 5, 5-32.

Asmus, E.P. \& Harrison, C.S. (1990). Characteristics of motivation for music and musical aptitude of undergraduage nonmusic majors. Journal of Research in Music Education, 38, 258-268.

Austin, J.R. (1988). The effect of music contest format on self-concept, motivation, and attitude of elementary band students. Journal of Research in Music Education, 36, 95-107.

Austin, J.R. (1991). Competitive and non-competitive goal structures: An analysis of motivation and achievement among elementary band students. Psychology of Music, 19, 142158.

Austin, J.R., Renwick, J. \& McPherson, G.E. (2006). Developing Motivation. In G.E. McPherson (ed). The child as musician: A handbook of musical development (pp 213-238). Oxford University Press, Oxford.

Austin, J.R. \& Vispoel, W.P. (1992). Motivation after failure in school music performance classes: the facilitative effects of strategy attributions. Bulletin of the Council for Research in Music Education, 111, 1-23. 
Austin, J.R. \& Vispoel, W.P. (1998). How American adolescents interpret success and failure in classroom music: Relationships among attributional beliefs, self-concepts and achievement. Psychology of Music, 26, 26-45.

Bakker, A.B. (2005). Flow among music teachers and their students: The crossover of peak experiences. Journal of Vocational Education, 66(1), 26-44.

Braten, I., \& Stromso, H.I. (2004). Epistemological beliefs and implicit theories of intelligence as predictors of achievement goals. Contemporary Educational Psychology, 29, 371-388.

Burland, K. \& Davidson, J. W. (2002). Training the talented. Music Education Research, 4(1), 121-40.

Burland, K., \& Davidson, J.W. (2004). The Role of Parents in the Development of the Professional Classical Musician. Edition Speciale de Sciences et Techniques en Activits Physiques et Sportives, 64, 89-108.

Cassie, V.K. (2008). Music makers: strings - teaching strategies for beginner orchestra class: Integrating seating arrangements and flow experience. Canadian Music Educator, 49(4), 5051.

Cattell, R.B. (1966). The scree plot for the number of factors. Multivariate Behavioural Research, 1, 245-276.

Chaffin, R. \& Lemieux, A.F. (2004). General perspectives on achieving musical excellence. In A. Williamon (ed.) Musical Excellence: Strategies and techniques to enhance performance (pp 19-40). Oxford: Oxford University Press.

Chandler, D., Chiarella, C., \& Auria, K. (1988). Performance expectancy, success, satisfaction, and attributions as variables in band challenges. Journal of Research in Music Education, 35(2), 249-258.

Comrey, A.L. \& Lee, H.B. (1992). A first course in Factor Analysis (2 ${ }^{\text {nd }}$ edition). Hillsdale, NJ: Lawrence Erlbaum Associates.

Costa-Gioma, E., Flowers, P.J. \& Sasake, W. (2005). Piano lessons of beginning students who persist or drop out: Teacher behavior, student behavior and lesson progress. Journal of Research in Music Education, 53(3), 234-247.

Coulson, S. (2010). Getting 'Capital' in the music world: musicians' learning experiences and working lives. British Journal of Music Education, 27(3), 255-270.

Creech, A. (2009). The role of the family in supporting learning. In S. Hallam, I. Cross \& M. Thaut (eds) Oxford Handbook of Music Psychology (pp. 295-306). Oxford: Oxford University Press 
Creech, A., Papageorgi, I., Duffy, C., Morton, F., Hadden, E., Potter, J., De Bezenac, C., Whyton, A., Himonides, E. \& Welch, G. (2008). From music student to professional: The process of transition. British Journal of Music Education, 25(3), 315-331.

Creech, A. \& Hallam, S. (2003). Parent-teacher-pupil interactions in instrumental music tuition: a literature review. British Journal of Music Education, 20(1), 29-44.

Creech, A. \& Hallam, S. (2011). Learning a musical instrument: the influence of interpersonal interaction on outcomes for school-aged pupils. Psychology of Music, 39(1), 102-122.

Csikszentmihalyi, M. (1991). Flow: the psychology of optimal experience. New York: Harper Row.

Davidson, J. W., Howe, M. J. A., Moore, D. G. and Sloboda, J. A. (1996). The role of parental influences in the development of musical ability. British Journal of Developmental Psychology, 14, 399-412.

Davidson, J.W., Moore, J.W., Sloboda, J.A. \& Howe, M.J.A. (1998). Characteristics of music teachers and the progress of young instrumentalists. Journal of Research in Music Education, $46,141-160$.

Duke, R.A., Flowers, P.J., \& Wolfe, D.E. (1997). Children who study with piano with excellent teachers in the United States. Bulletin of the Council for Research in Music Education, 132, 51-84.

Duke, R. \& Henninger, J. (1998). Effects of verbal corrections on student attitude and performance. Journal of Research in Music Education, 46(4), 482-495.

Eccles, J.S. \& Wigfield, A. (2002). Motivational beliefs, values and goals. Annual Review of Psychology, 53, 109-132.

Eccles, J.S., O’Neill, S.A. \& Wigfield, A. (2005). Ability self-perceptions and subjective task values in adolescents and children. In K. Moore and L.H. Lippman (Eds). What do children need to flourish? Conceptualising and measuring indicators of positive development (pp. 237-249). New York: Springer.

Evans, P., McPherson, G.E. \& Davidson, J. W. (2013). The role of psychological needs in ceasing music and music learning activities. Psychology of Music, 41(5), 600-619.

Finnas L (1987). Do young people misjudge each other's musical taste? Psychology of Music, 15, 152-166.

Finnas L (1989). A comparison between young people's privately and publicly expressed musical preferences. Psychology of Music, 17, 132-145.

Field, A. (2009). Discovering statistics using SPSS (Third Edition). Los Angeles: Sage publications. 
Gellrich M, Osterwold M and Schulz J (1986). Leistungsmotivation bei Kindern im Instumentalunterricht. Bericht uber eine erkundungsstudie. (Children's performance motivation in instrumental teaching) Musikpsychologie, 3, 33-69.

Guttman, L. (1954). Some necessary conditions for common-factor analysis. Psychometrika, 19, 149-161.

Hallam, S. (1998). The predictors of achievement and drop out in instrumental tuition. Psychology of Music,26(2), 116-132.

Hallam, S. (2002). Musical Motivation: Towards a Model Synthesising the Research. Music Education Research, 4(2), 225-244.

Hallam, S. (2013). What predicts level of expertise attained, quality of performance, and future musical aspirations in young instrumental players? Psychology of Music, 41(3), 265289.

Hallam, S. (2016). Motivation to learn. In S. Hallam, I. Cross \& M Thaut (eds) Handbook of Psychology of Music ( $2^{\text {nd }}$ edition) (pp 479-492). Oxford: Oxford University Press

Hallam, S. Rinta, T. Varvarigou, M., Creech, A. Papageorgi, I., and Lani, J. (2012). The development of practising strategies in young people. Psychology of Music, 40(5), 652-680.

Harnischmacher, C. (1997). The effects of individual differences in motivation, volition, and maturational processes on practice behaviour of young instrumentalists. In Jorgensen H. \& Lehman A (eds) Does practice make perfect? Current theory and research on instrumental music practice (pp 71-88). Norges musikkhgskole, Oslo.

Horn, J.L. (1965). A rationale and test for the number of factors in factor analysis. Psychometrika, 30, 179-185.

Howe, M.J.A. \& Sloboda, J.A. (1991). Young musicians' accounts of significant influences in their early lives 1 . The family and the musical background. British Journal of music Education, 8, 39-52.

Jollife, L.T. (1972). Discarding variables in a principal component analysis, 1. Artificial data. Applied Statistics, 21, 160-173.

Jollife, L.T. (1986). Principal Component analysis. New York: Springer.

Jorgensen, H. (2004). Strategies for individual practice In A. Williamon (ed) Musical Excellence: Strategies and techniques to enhance performance. (pp 85-103). Oxford: Oxford University Press

Jorgensen, H. \& Hallam, S. (2009). Practising. In S. Hallam, I. Cross, I. \& M Thaut (eds) Oxford Handbook of Music Psychology (pp 265-273). Oxford: Oxford University Press

Jorgensen, H. (1997). Time for practising? Higher level music students' use of time for instrumental practising. In H. Jorgensen \& A. Lehman (eds). Does practice make perfect? 
Current theory and research on instrumental music practice (pp 123-140). Norges musikkhgskole, Oslo.

Kaiser, H.F. (1960). The application of electronic computers to factor analysis. Educational and Psychological Measurement, 20, 141-151.

Kemp, A. (1996). The musical temperament: Psychology and Personality of Musicians. Oxford: Oxford University Press.

Kline, P. (1999). The handbook of psychological testing ( $2^{\text {nd }}$ edition). London: Routledge.

Klinedinst, R.E. (1991). Predicting performance achievement and retention of fifth-grade instrumental students. Journal of Research in Music Education, 39(3), 225-238.

Lacaille, N, Koestner, R., \& Gaudreau, P. (2007). On the value of intrinsic rather than traditional achievement goals for performing artists: a short term prospective study. International Journal of Music Education, 25(3), 245-257.

Lamont, A. (2002). Musical identities and the school environment. In R.A.R. MacDonald, D.J. Hargreaves \& D. Miell (eds). Musical Identities (pp 41-59). Oxford University Press, Oxford.

Legette, R.M. (1998). Causal beliefs of public school students about success and failure in music. Journal of Research in Music Education, 46(1), 102-111.

Legette, R.M. (2003). The effect of instruction on student self-concept and motivation. Missouri Journal of Research in Music Education, 40, 4-15.

Long, M., Gaunt, H., Creech, A. \& Hallam, S. (2010). Beyond the Conservatoire: a sociocognitive perspective on the development of professional self-concept among advanced music students. In Proceedings of the Students' Ownership of Learning Symposium at the Royal College of Music, Stockholm, 15 ${ }^{\text {th }}-17^{\text {th }}$ September, 2010.

MacNamara A, Holmes P. \& Collins, D. (2006). The pathway to excellence: the role of psychological characteristics in negotiating the challenges of musical development. British Journal of Music Education, 23, 285-302.

Manturzewska, M. (1990). A biographical study of the life-span development of professional musicians. Psychology of Music, 18, 112-139.

Martin, A.J. (2008). Motivation and engagement in diverse performance settings: Testing their generality across school, university/college, work, sport, music and daily life. Journal of Research in Personality, 42(6), 1607-1612.

McPherson, G.E. \& Davidson, J.W. (2002). Musical practice: mother and child interactions during the first year of learning an instrument. Music Education Research, 4(1), 141-156.

McPherson, G.A. \& McCormick, J. (1999). Motivational and self-regulated components of musical practice. Bulletin of the Council for Research in Music Education, 141, 98-102. 
McPherson, G.E. \& McCormick, J. (2000). The contribution of motivational factors to instrumental performance in a performance examination. Research Studies in Music Education, 15, 31-39.

McPherson, G.E. \& McCormick, J. (2006). Self-efficacy and performing music. Psychology of Music, 34, 322-336.

McPherson, G.E. \& O’Neill, S. (2010). Students' motivation to study music as compared to other school subjects: A comparison of eight countries. Research studies in music education, $32(2), 101-137$.

McPherson, G. \& Renwick, J. (2001). Longitudinal study of self-regulation in children's music practice. Music Education Research, 3(1), 169-186.

McPherson, G.E. \& Zimmerman, B.J. (2002). Self-regulation of musical learning. In R. Colwell \& C. Richardson (Eds) The New Handbook of Research on Music Teaching and Learning (pp. 348-372). New York: Oxford University Press.

Moore, D.G., Burland, K., \& Davidson, J.W. (2003). The social context of musical success: A developmental account. British Journal of Psychology, 94(4), 529-549.

Motte-Haber H. de la (1984). Die Bedeutung der Motivation fur den Instrumentalbericht (The significance of motivation in instrumental reports). Zeitschrift fur Musikpadagogik, 51, 51-4

Nagel, J.J. (1987). An examination of commitment to careers in music: Implications for alienation from vocational choice. Unpublished doctoral dissertation, University of Michigan, Ann Arbor, MI.

O'Connor, B.P. (2000). SPSS and SAS programs for determining the number of components using parallel analysis and Velicer's MAP test. Behaviour Research Methods, Instruments and Computers, 32(3), 396-402.

O’Neill, S.A. (1997). The role of practice in children's early musical performance achievement. In H. Jorgensen \& A.C. Lehmann (Eds.) Does practice make perfect? Current theory and research on instrumental music practice (pp. 53-70). Oslo: Norges musikkhogskole.

O'Neill, S.A. (1999). Flow theory and the development of musical performance skills. Bulletin of the Council for Research in Music Education, 141, 129-34.

O'Neill S.A. (1999). The role of motivation in the practice and achievement of young musicians. In SW Yi (ed). Music, mind and science (pp.420-433). Seoul National University Press, Seoul.

O'Neill, S.A. (2002). The self-identity of young musicians. In R.A.R. MacDonald, D.J. Hargreaves, \& D. Miell (Eds) Musical Identities. (pp 79-96). Oxford: Oxford University Press. 
O’Neill, S.A. \& McPherson, G.E. (2002). Motivation In R. Parncutt \& G.E. McPherson (eds) The Science and Psychology of Musical Performance: Creative Strategies for Teaching and Learning (pp 31-46). New York: Oxford University Press.

Papageorgi, I., Haddon, E., Creech, A., Morton, F., de Bezenac, C. Himonides, E., Potter, J., Duffy, C., Whyton, T. \& Welch, G. (2010). Institutional culture and learning I: perceptions of the learning environment and musicians' attitudes to learning. Music Education Research, 12(2), 151-179.

Papageorgi, I., Hallam, S., \& Welch, G. (2007). A conceptual framework for understanding musical performance anxiety. Research Studies in Music Education, 28(1), 83-107.

Patrick, H., Ryan, A.M., Alfred-Liro, C., Fredricks, J.A., Hruda, L.Z. \& Eccles, J.S. (1999). Adolescents' commitment to developing talent: The role of peers in continuing motivation for sports and the arts, Journal of Youth and Adolescence, 28(6), 741-763.

Persson, R.S., Pratt, G. \& Robson, C. (1996). Motivational and influential components of musical performance: A qualitative analysis. In A.J. Cropley \& D. Dehn (eds). Fostering the Growth of High Ability: European Perspectives (pp. 287-301). Ablex, Norwood, NJ.

Pitts, S., Davidson, J. \& McPherson, G.E. (2000a). Developing effective practising strategies: Case studies of three young instrumentalists. Music Education Research, 2(1), 45-56.

Pitts, S. E., Davidson, J.W., \& McPherson, G.E. (2000b). Models of success and failure in instrumental learning: Case studies of young players in the first 20 months of learning. Bulletin of the Council for Research in Music Education, 146, 51-69.

Renwick, J.M. \& McPherson, G.E. (2002). Interest and choice: Student-selected repertoire and its effect on practising behaviour. British Journal of Music Education, 19, 173-188.

Sandane, B.A. (1998). An investigation of variables related to student motivation in instrumental music. Dissertation Abstracts International, 58, 3870A. (UMI No. 9811178)

Schmidt, C.P. (2005). Relations among motivation, performance achievement, and music experience variables in secondary instrumental music students. Journal of Research in Music Education, 53, 134-147.

Sichivitsa, V.O. (2007). The influences of parents, teachers, peers and other factors on students' motivation in music. Research Studies in Music Education, 29(1), 55-68.

Sloboda, J.A. \& Howe, M.J.A. (1991). Biographical precursors of musical excellence: an interview study. Psychology of Music, 19, 3-21.

Smith, B.P. (2005). Goal orientation, implicit theory of ability, and collegiate instrumental music practice, Psychology of Music, 33(1), 36-57.

Sosniak, L.A. (1985). Learning to be a concert pianist. In B.S. Bloom (ed). Developing talent in young people (pp. 19-67). Ballentine, New York 
Stevens, J.P. (2002). Applied Multivariate statistics for the social sciences ( $4^{\text {th }}$ edition). Hillsdale, NJ: Erlbaum.

StGeorge, J. (2010). The subjectivity of musical learning: Understanding participation in instrumental music instruction. Unpublished PhD, University of Newcastle, New South Wales.

Szubertowska, E. (2005). Education and the Music Culture of Polish Adolescence. Psychology of Music, 33, 317-330.

Tabachnick, B. G., \& Fidell, L. S. (2001). Using multivariate statistics (4th ed.). Boston, MA: Allyn and Bacon, Pearson International.

Vispoel, W.P. (1993). The development and evaluation of a computerized adaptive test of tonal memory. Journal of Research in Music Education, 41, 111-136.

Vispoel, W.P. \& Austin, J.R. (1993). Constructive response to failure in music: The role of attribution feedback and classroom goal structure. British Journal of Educational Psychology, 63, 110-129.

Werner, E. E. (1995). Resilience in development Current Directions in Psychological Science, 4, 81-85

Wigfield, A., Eccles, J.S., Yoon, K.S., Harold, R.D., Arbreton, A.J.A., Freedman-Doan, C. \& Blumenfield, P.C. (1997). Changes in children's competence beliefs and subjective task values across the elementary school years: A 3-year study. Journal of Educational Psychology, 89, 451-469.

Zdinski, F.S. (1996). Parental involvement, selected student attributes and learning outcomes in instrumental music. Journal of Research in Music Education, 44(1), 34-38.

Zdzinski, A. (2013). The underlying structure of parental involvement - home environment in music. Bulletin of the Council for Research in Music Education, 198(fall) 69-88. 